\title{
Assessment of production and marketing constraints and value chain of sweet potato in the municipalities of Dangbo and Bonou
}

\author{
Vincent Ezin ${ }^{1 *}$, Florent Quenum', Roméo Houénagnon Bodjrenou' ', Chabrolle M. I. Kpanougo', \\ Emeric M. G. Kochoni ${ }^{2}$, Bienvenu Ifagbémi Chabi ${ }^{3}$ and Adam Ahanchede ${ }^{1}$
}

\begin{abstract}
Background: Sweet potato [lpomoea batatas (L.) Lam.] plays an important role in ensuring food security and incomes for local communities. It is particularly grown in southern region of Benin, and its production over the last few years has declined due to disease and severe pest infestation. Therefore, it was imperative to carry out this study to identify the main constraints related to the recent decline in sweet production and more specifically analyzing the production and marketing constraints of sweet potato in the townships of Dangbo and Bonou.

Results: The results of the survey revealed that many varieties of sweet potato were grown, mainly "Vobodouaho" (local name in Goun language), the most preferred variety by producers. Weedicides and insecticides were used to control weeds and insect pests, respectively. There was no efficient control methods against black rot, Alternaria blight, cylas spp., and caterpillar among the pathogens and insects that damaged sweet potato production in the study areas. The main constraints reducing sweet potato production in the townships of Dangbo and Bonou are: lack of adequate methods for controlling pest and diseases, lack of financial resources due to no access to credit, absence of modern equipment, scarcity and high cost of labor and absence of best methods for long-term storage. The average yield of sweet production per hectare ranged from 6.5 to 15.1 tons fresh matter/ha. The market value of sweet potato is still low at farmers' level when compared to that of other stakeholders along the value chain.
\end{abstract}

Conclusion: This study calls for the attention of public and private sectors and policy makers for more investment in sweet potato research. Avenues for further research on sweet potato have also been suggested.

Keywords: Actors in sweet potato, Horticulture, Limitations, Productivity, Revenue

\section{Background}

Benin is an essentially agricultural country where $70 \%$ of the population lives in rural areas [1]. This population basically practices agriculture of subsistence. Among the main staple food crops cultivated are tubers and roots. In order to encourage the development of these crops and improve their contribution to the food security, Benin government, through its policy of diversification of agricultural production and fight against poverty, has initiated the Program of Development of Tubers and

\footnotetext{
*Correspondence: ishola.vincent@yahoo.com; awevincent@gmail.com

1 Department of Crop Production, Faculty of Agricultural Science,

University of Abomey-Calavi, Abomey-Calavi, Benin

Full list of author information is available at the end of the article
}

Roots (PDRT) in collaboration with partners for development such as International Fund for Agricultural Development (IFAD) and West African Bank of Development (BOAD) [1]. The program aims at rationalizing sustainably production, transformation and marketing of tubers and roots through reinforcement of technological capacities. Among tubers and roots are cassava, taro, yam, potato and sweet potato. The findings of the present research strengthen the Ministry of Agriculture in its program of intensify tubers and roots and ultimately stimulate calls for attention for more investment in sweet potato research in order to help farmers increase their productivity and revenues. Sweet potato can adapt to different ecological conditions and requires 
few inputs for its cultivation [2]. It is an important food and vegetable crop in most developing countries where it was ranked fifth economically after rice, wheat, maize and cassava [3]. Sweet potato is grown mainly for the fresh market. The fresh market sweet potato tubers are sold in the surrounding markets around the study areas, which need to be improved upon for high price and subsequent high income. The sweet potato value chain of different innovative platform approaches is required to facilitate work in the farms and postharvest operations and at the same time improve the quality of sweet potato products including improve nutritional value and food and nutritional security; and strengthen the capacity of all stakeholders in order to alleviate poverty along the value chain.

From nutritional point of view, all the parts of sweet potato are rich in food fibers, the leaves and the stems contain high content in minerals, particularly iron and carotene, vitamin B2, vitamin C and vitamin E [4]. The tubers of sweet potato are rich in starch, sugar, vitamin $\mathrm{C}, \beta$-carotene, iron and several other minerals [5-7]. According to [6], sweet potato tubers proved to be richer in proteins than cassava and the yam tubers. All these features indicate that sweet potato is an important crop capable of playing a significant role in food security. In spite of these assets, sweet potato still remains a marginalized crop in the development programs of the country. Moreover, from 2012 to 2015, the area of production of sweet potato compared to other tubers and roots declined from 2.21 to $2.01 \%$ and a decrease in production from $69,829.43$ to $55,404.97$ tons was also recorded; henceforth, a slight reduction in production area, i.e., $0.20 \%$ and a drastic yield reduction of $20.65 \%$ [8]. It has been basically due to a certain number of factors such as pathogens, weevils (Cylas spp.), sweet potato virus disease, low market value tubers harvested by farmers, lack of certified planting materials resistant to abiotic and biotic elements and modern storage facilities for long-term conservation. Jackai et al. [9] reported that there are losses of millions of dollars annually only due to infestation of sweet potato by weevils and these insect pests are more prevalent in the tropical regions. Based on this decline in sweet potato production and taking into account its high potentiality, it could be important to intensify research efforts to increase its production for the benefit of the producers and consumers and sort out the problem of food insecurity. To this end, this survey was conducted in the valley of Benin more precisely in the townships of Dangbo and Bonou to analyze the techniques of production systems and marketing of the sweet potato by identifying the constraints that prevent the development of this sector.

\section{Methods}

\section{Study site and choice of study area}

The municipalities of Dangbo and Bonou are located in the department of Ouémé. Dangbo Township is bounded in the north by Adjohoun Township, in the south by Aguégués Township, in the east by Akpro-Missérété Township and in the west by Sô-Ava Township. As for Bonou, it is bounded in the north by the Ouinhi Township, in the south by Adjohoun, in the east by Sakété and Adja-Ouèrè Townships and in the west by Zê and Zogbodomé Township. Dangbo and Bonou cover a total land area of 149 and $250 \mathrm{~km}^{2}$, respectively.

With the poor distribution of rainfall observed nowadays, the seasons underwent noticeable change (PDC2 Bonou, 2013-2017). In the last 20 years, the total average annual rainfall is $1237 \mathrm{~mm}$ (ASECNA, 2012) with a temperature that varies between 25 and $30{ }^{\circ} \mathrm{C}$. The number of rainy days turns around 135 days per year and the period of vegetative growth varies between 229 and 251 days.

The valley of Ouémé consists of four municipalities, namely Dangbo, Bonou, Adjohoun and Aguégué. Our survey was conducted in Dangbo and Bonou Municipalities. Each municipality is divided into several villages among which ten were investigated (Fig. 1).

These villages were chosen for two main reasons:

- Favorable zones for sweet potato production. Given that the needs in water of the sweet potato are estimated at $600 \mathrm{~mm}$ of water per cycle, with high quantity of water at the early stages of crop development and adequate temperatures between 22 and $33{ }^{\circ} \mathrm{C}$, and it is also required between 120 and 210 days for crop development [10]. We can say that the rainfall conditions and temperature in the survey zone are propitious to the requirements of the sweet potato production; and

- Areas of high sweet potato production.

\section{Sampling and data collection}

In order to achieve the objectives of this work, the survey was carried out in two (02) phases: an exploratory phase and an in-depth survey phase.

The exploratory phase consisted in establishing contact with people in charge of CARDER (Regional Action Center for Rural Development), the different producers of the two townships. The contact was established through the person in charge of rural development and the adviser in crop production representing the ministry of agriculture in the locality for the list of farmers growing sweet potato.

The exploratory survey enabled us to obtain some primary information about sweet potato through 

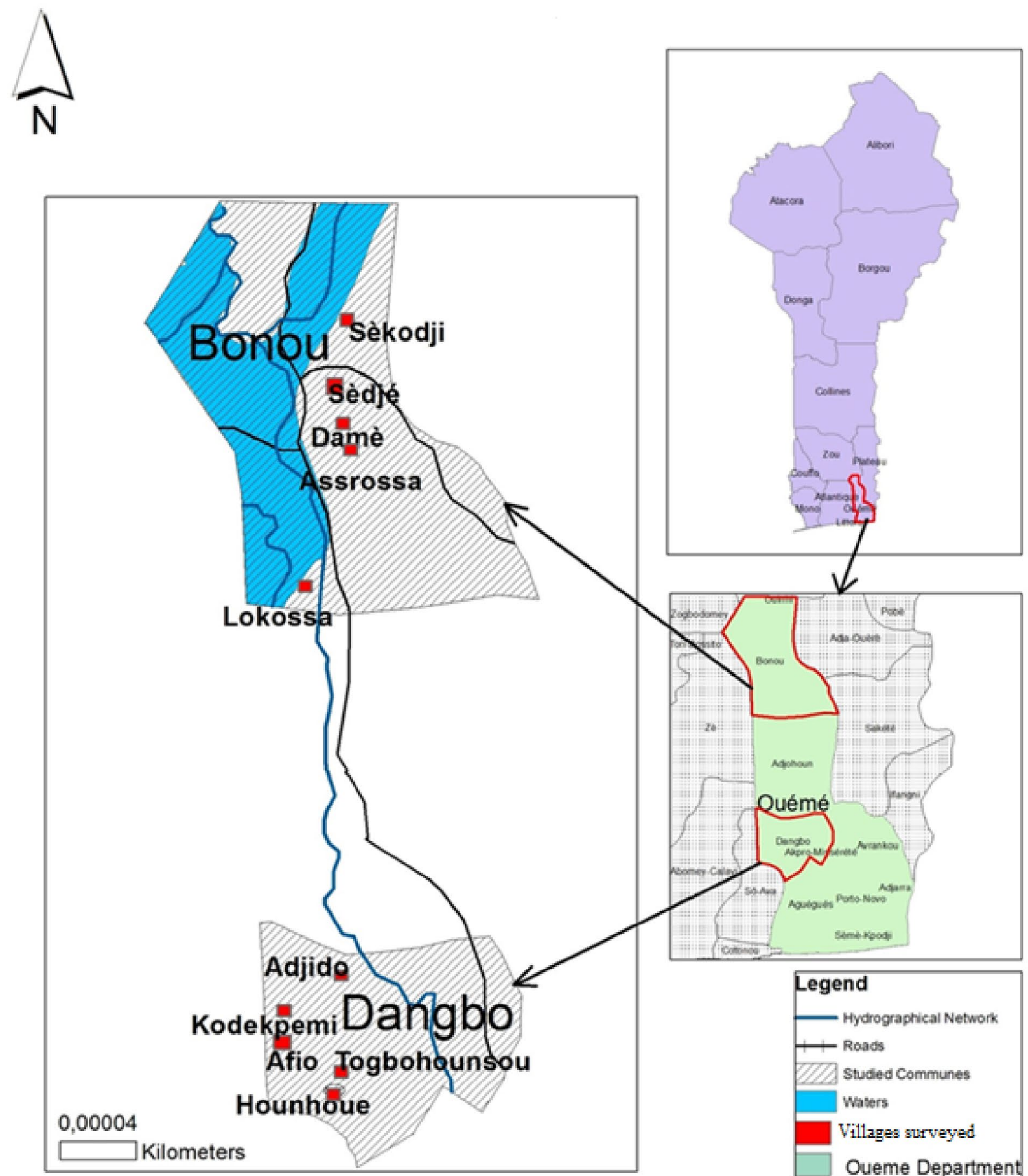

Fig. 1 Geographical localization of the ten villages investigated

interview with producers (target group and individual discussion) selected randomly and observations made in the field. This phase was also of great help for setting proper questionnaire for the in-depth phase.
In the in-depth survey phase, a total of 150 producers were randomly surveyed but due to the heavy infestation of caterpillars and cylas spp. and some pathogens in the last few years, complete information were obtained only 
from 100 producers while incomplete information were obtained from those who abandoned sweet potato production as at the time of the study. Thus, 100 producers with complete information were used in this study. Therefore, the producers were surveyed through interviews, participating and/or direct observations and focus group. Qualitative and quantitative data were collected. The parameters included sex, age, size of the household, level of education, cropped area, number and types of varieties, mode of land acquisition, and types of labor, soil fertility management, development phase and yield of the sweet potato. The producers were ranked based on the size of areas cropped as follows: cropped area lesser than 1 ha as small producers; between 1 and 2 ha as average scale farmers and cropped area greater or equal to 3 ha as large scale producers. As far as the constraints are concerned, they were ranked based on farmers' percentage.

\section{Data analysis}

The collected data in survey sheets were examined and codified and then entered into Microsoft Excel. The descriptive statistics with the aid of Minitab software was computed and averages, frequencies, minimum and maximum of some parameters such as sex, age, size of the household, the level of education and the availability of the land were determined.

\section{Results}

\section{Profile of farmers}

The producers of sweet potato investigated in the township of Bonou and Dangbo were all native (40\% were from sèto and $60 \%$ from Whémé). Majority of sweet potato producers in study area were men (56\%) with ages between 40 and 60 years while those of less than 40 years and older than 60 years were $12 \%$ (Table 1). This important number of men in sweet potato production could be justified by the toughness of the works on the vertisols. About $80 \%$ of respondent households were within the range of working age ( $<40$ to 60 years old), whereas only $12 \%$ of them were elder ( $>60$ years old). Despite the high number of men, an increase in women in some tasks such as cutting of vines, planting and tuber gathering for storage were observed.

The education level of respondents surveyed is presented in Fig. 2. From the analysis of this figure, most of producers did not attend schools and were primary school dropouts.

Table 2 shows the classification of respondents according to the cultivated areas. From the analysis of the results, $44 \%$ of respondents grew sweet potato on farmland of 1 to 2 ha, $36 \%$ in lesser than 1 ha of land and $20 \%$ of respondents in 3 ha of land.

Figure 3 shows the distribution of the respondents according to the mode of access to land. The analysis of the results of Fig. 3 reveals that the mode of access to land the most observed was the inheritance (50\%) followed by purchase $(30 \%)$ and renting $(20 \%)$. It should be noted that women were less involved in farm activities due to the fact that they are not entitled to land heritage in Africa context, mainly because of their significant roles in the household affairs.

Table 3 shows the different types of labor used by producers. The analysis of the results of this table reveals that the most observed was labor (75\%) followed by family workforce (25\%). Mutual aid was also observed in complement of family workforce. Family labor was only used during weekend and holidays. Male producers made use of the two types of labor whereas female producers

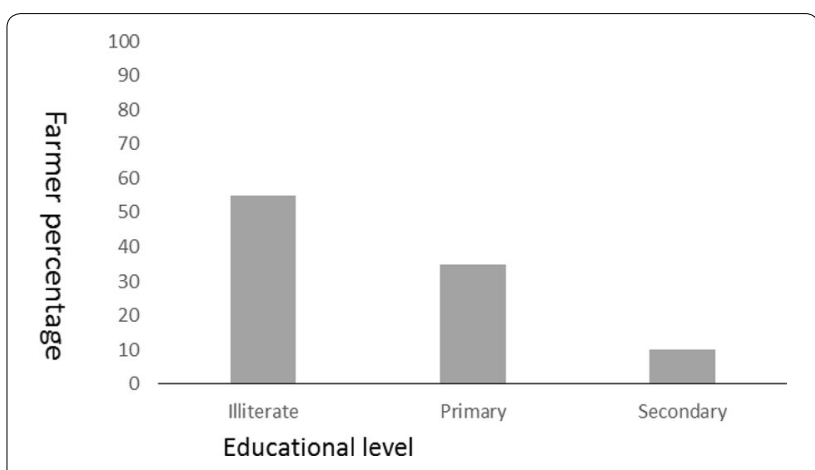

Fig. 2 Educational level of producers investigated

Table 1 Socio-demographic characteristics of respondents according to their age, sex, ethnic group and townships

\begin{tabular}{|c|c|c|c|c|c|c|c|c|}
\hline \multirow[t]{3}{*}{ Township } & \multicolumn{6}{|c|}{ Age } & \multicolumn{2}{|c|}{ Ethnic group } \\
\hline & \multicolumn{2}{|c|}{$<40$} & \multicolumn{2}{|c|}{$40-60$} & \multicolumn{2}{|c|}{$>60$} & \multirow[t]{2}{*}{ Sèto } & \multirow[t]{2}{*}{ Whémé } \\
\hline & $M$ & $\mathbf{F}$ & $M$ & $\mathbf{F}$ & $M$ & $\mathbf{F}$ & & \\
\hline Bonou & 10 & 0 & 32 & 10 & 8 & 0 & & 60 \\
\hline Dangbo & 2 & 2 & 24 & 8 & 4 & 0 & 40 & \\
\hline Total & 12 & 2 & 56 & 18 & 12 & 0 & 40 & 60 \\
\hline Frequencies (\%) & 12 & 2 & 56 & 18 & 12 & 0 & 40 & 60 \\
\hline
\end{tabular}


Table 2 Typology of producers according to the areas cultivated

\begin{tabular}{|c|c|c|c|c|c|c|c|}
\hline \multirow[t]{3}{*}{ Areas cultivated } & \multirow[t]{3}{*}{ Sex } & \multicolumn{4}{|c|}{ Townships } & \multirow{2}{*}{\multicolumn{2}{|c|}{ Total }} \\
\hline & & \multicolumn{2}{|l|}{ Bonou } & \multicolumn{2}{|l|}{ Dangbo } & & \\
\hline & & Number & Fre $\%$ & Number & Fre $\%$ & Number & Fre $\%$ \\
\hline \multirow[t]{2}{*}{$<1$ ha } & Male & 16 & 16 & 8 & 8 & 36 & 36 \\
\hline & Female & 4 & 4 & 8 & 8 & & \\
\hline \multirow[t]{2}{*}{$1-2$ ha } & Male & 20 & 20 & 2 & 2 & 44 & 44 \\
\hline & Female & 4 & 4 & 18 & 18 & & \\
\hline \multirow[t]{2}{*}{$>3$ ha } & Female & 14 & 14 & 4 & 4 & 20 & 20 \\
\hline & Female & 2 & 2 & 0 & 0 & & \\
\hline Total & & 60 & 60 & 40 & 40 & 100 & 100 \\
\hline
\end{tabular}

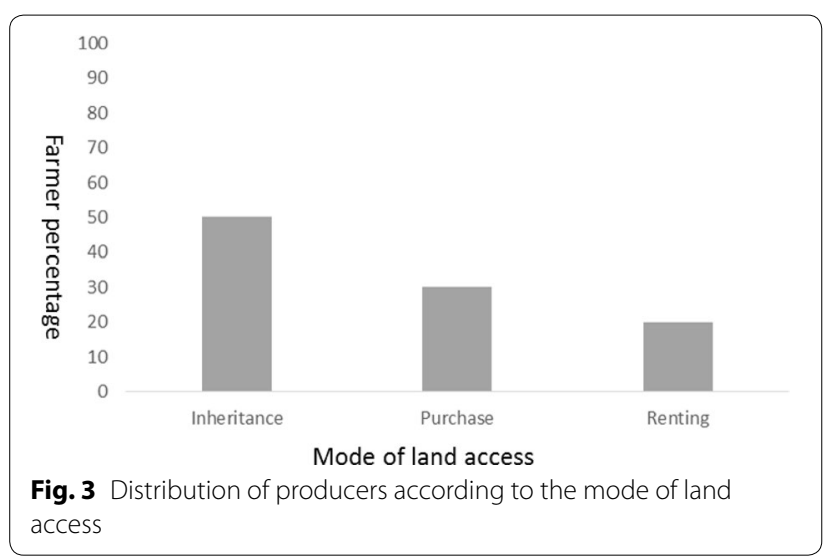

Table 3 Different types of labor used by the producers

\begin{tabular}{lcc}
\hline Labor & Number & Frequency (\%) \\
\hline Labor & 75 & 75 \\
Family aid & 25 & 25 \\
Total & 100 & 100 \\
\hline
\end{tabular}

often dependent on their husbands for help and occasionally used labor to supplement the family assistance. It should also be noted that in addition to the high cost paid to manpower, producers also provided foods to the workers during the period they carried out the work in the field.

Capital funds invested in the production of sweet potato by farmers include their own funds and loans. Their own funds were from other agricultural-related activities. Producers took loans at interest from different agricultural banks such as CLCAM (Local Bank for mutual agricultural loan) and ASF (Association of Financial Services), to be able to face labor payment and other input activities. The loans were repaid at interest rate of
$22 \%$. The main constraints to loan access are several formalities to complete at the banks, the long distance that separates these banks from producers, the non-return of the loans by some farmers in past and the high interest rate.

\section{Sweet potato production and storage: constraints and adaptive strategies}

The propagation by cuttings was performed 2 weeks after the application of herbicides. It should be noted that problem of input supply arises in the study area. The problem of weedicide and insecticide supply in the study area could be justified by the long distance between the area of cultivation and CARDER headquarter especially because of the river of Ouémé separating the two sites. Some producers buy an important quantity (liters) of pesticides that is more than what is needed for their farms and resell at high price to other producers. The cost of a liter of the inputs ranged between 4000 and 5000 FCFA (US $\$ 8$ and US \$10) when bought from CARDER and 5000-6000 FCFA (US \$10-12) when bought from local sellers. The majority of farmers used sweet potato planting material from their previous crop or from their neighbors.

The land preparation consists in cutting weeds with the aid of sickles on the ridges of previous season. According to the majority of producers, this allows the decomposition of weed residues which are sources of nutrients to the growing sweet potato plants for better productivity. Moreover, it also helps to manage the harmful pests by destroying their habitat and also by preventing the resumption of the adventitious tubers. To facilitate the work, the producers applied SHARP herbicide at a rate of $480 \mathrm{~g} / \mathrm{L}, 2$ weeks before land clearing.

Irrigation (Fig. 4) was applied during the dry season to facilitate the plowing and water supply to plants. About $(80 \%)$ of producers interviewed applied irrigation during dry season for out-season production. 


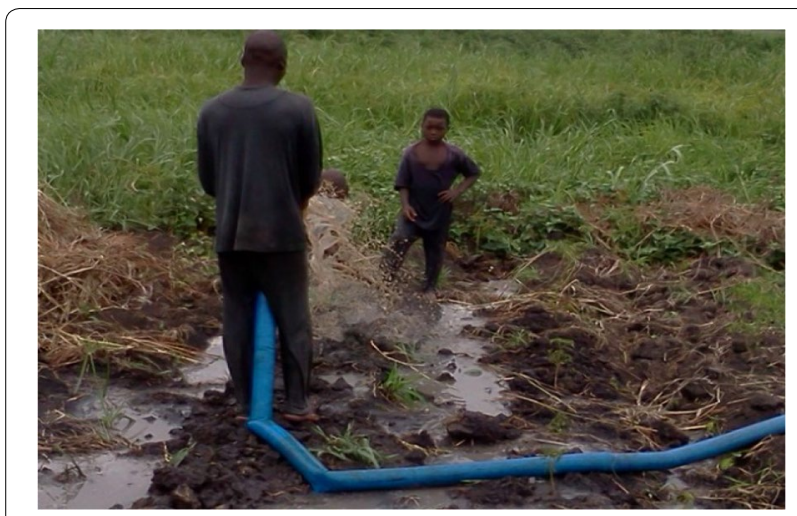

Fig. 4 Land irrigation
Table 4 Traits of varieties of sweet potato grown in Bonou and Dangbo

\begin{tabular}{llll}
\hline Morphotypes & Color skin & Water content & $\begin{array}{l}\text { Ability } \\
\text { for storage }\end{array}$ \\
\hline Adjlè & White & Moderately low & Good \\
Atakan & White & Moderately low & Good \\
Ahotonon & Red & Moderately low & Poor \\
Amiwèdé & White & Low & Good \\
Zohoun & Red & Moderately low & Good \\
Vobodouaho & White & High & Poor \\
Adogoun & White & Moderately low & Poor \\
Minché & White & Moderately low & Poor \\
\hline
\end{tabular}

The water content is based on farmer perspective

"Vobodouaho" means you can be in debt without worrying. According to the producers, this variety by its high productivity enables them to pay their debts.

According to the producers surveyed, the harvests were performed at harvest maturity but there was also early harvest which was done at physiological maturity due to flooding. The potato reaches its physiological maturity when the stems and leaves began yellowing and leaves started dropping. The harvest usually starts in April and ends in August. When it rains and the ridges are half flooded, the producers immediately harvest them. The men carried out the harvesting and the women picked up with a basin and then transport them to the place of packaging.

The producers surveyed have several storage methods. A first method consists on gathering the tubers in heaps and covering them with plant debris (Fig. 5). The storage period varies between 1 and 2 months if the ridges were not flooded before harvest. A second method consisted in packaging the sweet potatoes in the bags and covering them with vegetable debris (Fig. 6). None of the producers interviewed had sophisticated facilities for long period of storage.

All the producers surveyed estimated that for two ridges (of $6 \mathrm{~m}$ long each) an average of $55 \mathrm{~kg}$ was harvested but in case of pest attack at least six ridges of sweet potato were required before obtaining the $55 \mathrm{~kg}$ which reduced the average yield to about 6.5 tons/ha. Therefore, the average yield of sweet production per hectare without disease and pest infestation and at optimal conditions was 15.125 tons.

The main constraints were diseases and insects viz black rot, Alternaria and caterpillars (Lepidoptera larva), which cause serious damage to the tubers (Fig. 7). This insect is called "Hlo" in local language. The causal agent of black rot was identified as Ceratocystis fimbriata while that of Alternaria species was Alternaria solani and preferred by consumers, short cycle of 4 months, high yields and big tubers when compared to other varieties. 


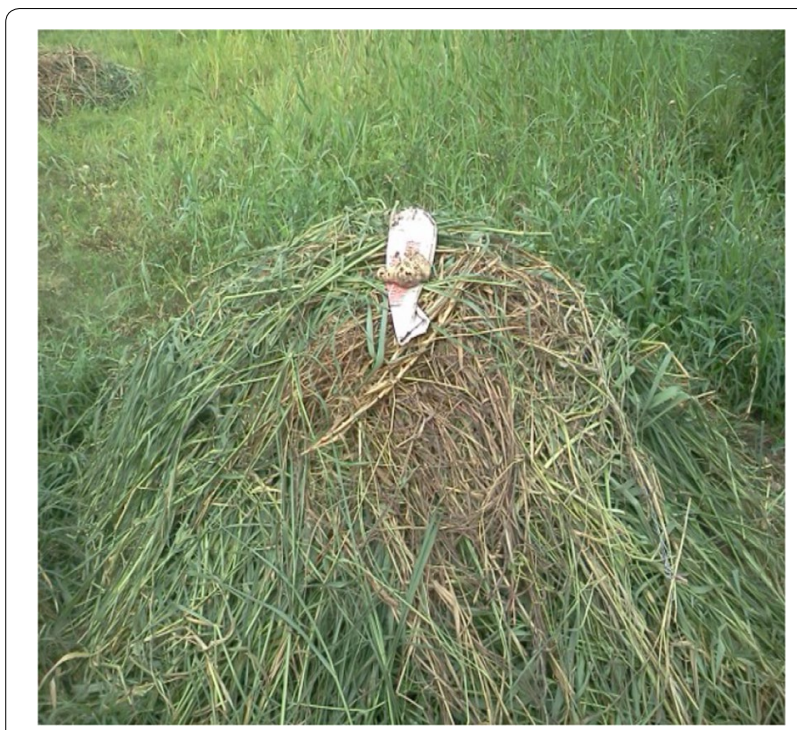

Fig. 5 Heaping of sweet potatoes on the farm

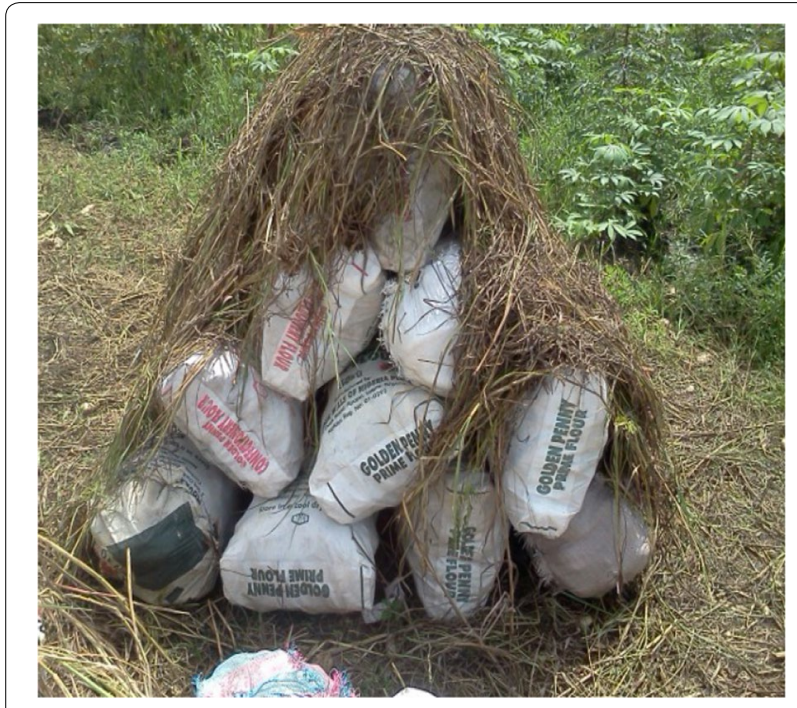

Fig. 6 Storage in bags of sweet potatoes

insect was identified as Acraea acerata commonly known as "wanvi" in local language by producers. Another insect species identified was Cylas puncticollis, a weevil, known as vâ in local language, and it does cause galleries (hollows) on tubers (Fig. 8). It causes the root losses resulting in crop failure. It also leads to poor quality of tubers that are no longer accepted in the market. Ceratocystis fimbriata caused the yellowing of young leaves and the blackening of the underground parts of the stem while it caused circular holes on the tubers. Alternaria solani showed brown rings on the leaves and black lesions on the petiole and stem. The matured leaves were the most attacked. Acraea acerata attacked the leaves by perforating them. In the dry season, this caterpillar caused tremendous damage and resulted in poor yields (Fig. 7). To control this insect, the producers used active ingredient of super action insecticides and super cydim containing cypermethrin. It should be noted these insecticides are normally used for other market gardeners, which are not specific to sweet potato pests. None of these pesticides control Cylas puncticollis as reported by the farmers. Further studies must then be initiated to find the most suitable pesticides and other control measures for the control of sweet potato pests and diseases.

Other constraints identified by farmers surveyed were high temperatures, high moisture content of tubers, flooding of potato fields and late harvesting. Producers also listed weeds as serious constraints in the Ouémé valley where the lands are rich in nutrients. Some producers used herbicide SHARP 480 SL as control measures.

Table 5 presents the various constraints in order of importance as perceived by the producers and the adaptation strategies developed.

The adaptation strategies developed by the producers aim at reducing the effects of these constraints for a good productivity of sweet potato.

\section{Marketing of sweet potato products and constraints}

Producers marketed their sweet potato produces in several local markets, namely Dangbo, Ouando (PortoNovo), Tatonnonkon, Dasso, Assrossa, Bonou and Dantokpa (Cotonou). But none of the producers did export their products to the subregion and international markets. The marketing options include direct sales to consumers and selling to wholesalers or retailers. During the periods where sweet potato tubers are much more available, the supply becomes greater than the demand. This causes the producers to sell their products at a low price. This is due to the lack of storage facilities and the financial needs of producers. The sweet potato tubers were sold either in a basin (Fig. 9) or packed in bags and transported by canoes (Fig. 10) to the markets. The basket was between 3500 and 4000 FCFA and the bag was 6000 FCFA. There is rapid growth in demand for sweet potato in urban areas because it is fried every afternoon in every corner of the cities and it is also boiled but in rural areas it is boiled and pounded together with yam and eat as food with sauce. This has created huge opportunities to sell and market sweet potato in urban and rural areas. The main constraints in marketing sweet potato tubers is due to the infestation of some tubers by insect pests which lower its quality and nutritional value and therefore make the consumers not to be interested in it because oftentimes some farmers fail to remove the damaged tubers from the healthier ones. But most often 


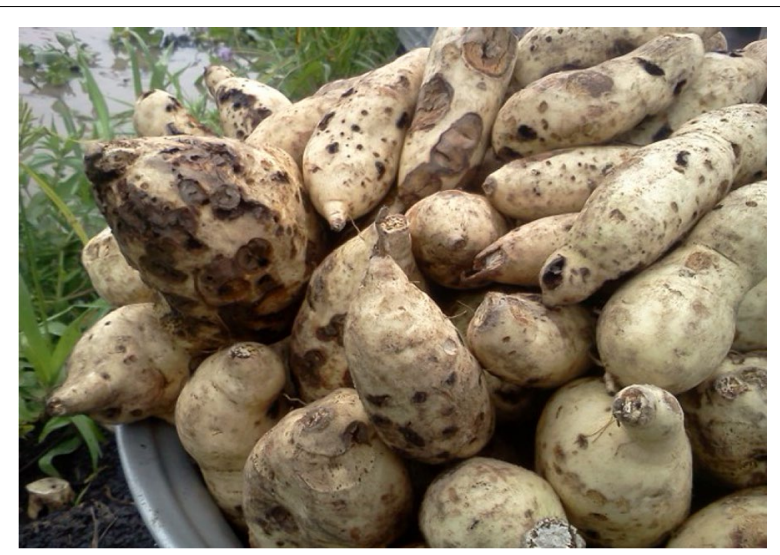

Fig. 7 Decayed tubers due to the attack of caterpillar

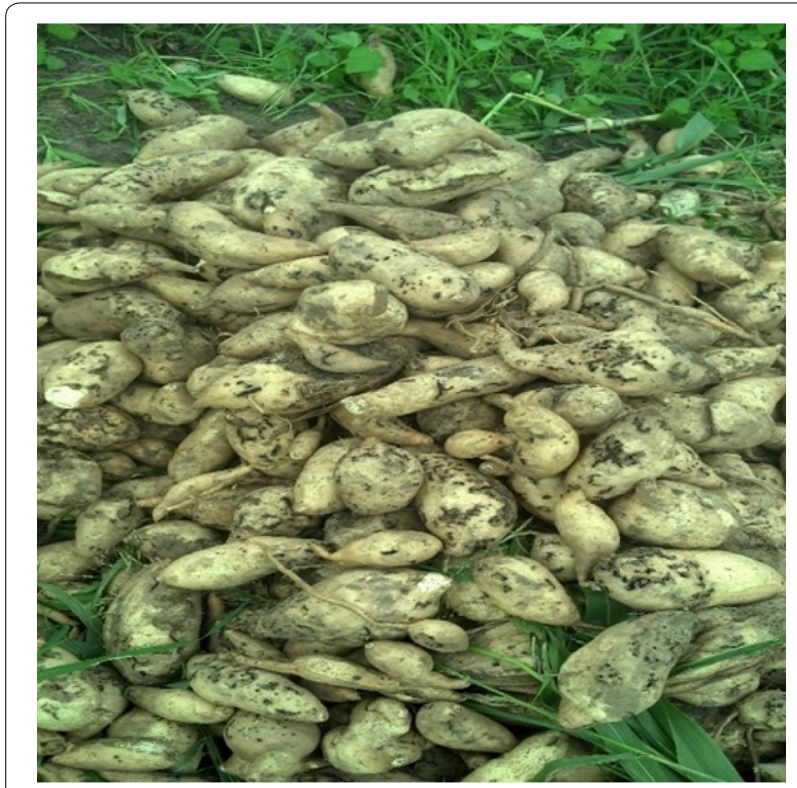

Fig. 8 Some sweet potato tubers attacked by Cylas puncticollis

it is sold at low price due to the low marketable root yields, which lead to low income.

\section{Value chain of sweet potatoes}

The actors involved in the value chain are: producers, wholesalers, semi-wholesalers, retailers, transporters and consumers (Fig. 11). The producers were the sweet potato farmers. They were involved in field production and they do receive input supply from CARDER and informal agencies who bought their inputs from Nigeria. After harvest, the sales were carried out in the fields. The wholesalers were big traders of the locality; they bought directly from the producers and the basket of sweet potato is sold at 3500 FCFA. The semi-wholesalers bought the wholesale from wholesalers; they were traders and they bought in large quantities at a price that could be estimated at 5000 FCFA/basket. The retailers bought agricultural products at relatively high prices (7000 FCFA/basket) from semi-wholesalers compared to the purchase price practiced by semi-wholesalers from the wholesalers and the wholesalers from producers. They were market traders. The consumers bought from retailers for their own food needs. They bought at a relatively higher price. The semi-wholesalers sell 4 to 5 tubers per heap (200-400 FCFA) to the consumers. The producers preferred to sell their products to wholesalers instead of going to the market in order to avoid paying transport fees. The transporters were responsible for transporting products from the fields to the markets.

\section{Discussion}

The leaders of households interviewed were mostly males as the case in other African countries. Our results are similar with those of [11] who reported that over $60 \%$ of the farmers surveyed were men in their study in Kenya. $55 \%$ of the respondents were illiterate and only $35 \%$ completed primary education (Fig. 2). This is below the mean national literacy level of adults to adopt some agricultural technologies. So, the illiteracy of farmers could be the raison behind some poor agricultural practices observed in the field, and the low yield recorded year after years. They could not read the instructions on the label on the inputs used unless they are associated with somebody who can help. But these producers were experienced enough to apply some good agricultural practices. These results are not consistent with those of [12] who reported that most (54.2\%) of the interviewed households completed primary education in southern Ethiopia, same results were obtained by [13].

The production of sweet potato in the studied areas is still traditional. Crop production practices are carried out manually using rudimentary tools such as hoe, cutlass. The main difficulty was related to the preparation of the soil by making ridges, a difficult task on clay soils of the areas of study due to the rudimentary tools used. The $88 \%$ of respondents within the range of working age possess the physical strength required to face the challenge of sweet potato production with the use of rudimentary tools. Under these conditions, the use of modern tools for the production of sweet potato should be explored in order to reduce the difficulties associated with sweet potato production. In another words, the use of oxen and tractors would be of great help in plowing, weeding and harvesting, which will reduce root damages especially during harvesting. In relation to planting, there is always problem of plant material scarcity, i.e., lack of vines or seed tubers. Producers often do not 
Table 5 Constraints in order of importance and coping strategies

\begin{tabular}{|c|c|c|c|}
\hline Constraints & Adaptive strategies & Rank & $\%$ farmers \\
\hline Climate hazards (flood and submergence) & Temporary abandonment of fields & 1 & 39 \\
\hline Absence of modern's equipment for production & Use of available means and materials of production & 2 & 20 \\
\hline Lack of adequate methods for pests management & $\begin{array}{l}\text { Use of chemical products intended to market gardening } \\
\text { to reduce pest damage }\end{array}$ & 3 & 10 \\
\hline Scarcity and expensiveness of labor & Use of family workforce, labor and mutual aid & 4 & 8 \\
\hline Toughness of activities & High use of labor & 5 & 7.5 \\
\hline Absence of best storage methods for a long time & Immediate sale of tubers after harvest & 6 & 6 \\
\hline Inexistence of road system for tubers transport to the market & Using pirogue to transport sweet potatoes & 7 & 5.5 \\
\hline Slump in sales during harvest of tubers & $\begin{array}{l}\text { Early harvest of tubers and choice of short-cycle varieties } \\
\text { (Vobodouaho et minché) }\end{array}$ & 8 & 3 \\
\hline $\begin{array}{l}\text { Lack of training and aid to the members of their associations and } \\
\text { from agricultural extension agents }\end{array}$ & Use of traditional practice for the production & 9 & 1 \\
\hline
\end{tabular}

have planting material for the next growing season. This problem is exacerbated by the flood from the overflowing of the river which invades their field coupled with the lack of supervision and training. Therefore, a training of producers is necessary in order to provide all the technical assistance for the best cultivation of the crop [1], particularly on the techniques of planting and multiplication of cuttings and their conservation for next growing season. Sweet potato was mainly planted on ridges and the density of seedlings was about 33,333-46,667 plants per hectare. These values were relatively higher than the ones recommended by [14], which is 30,000 plants per

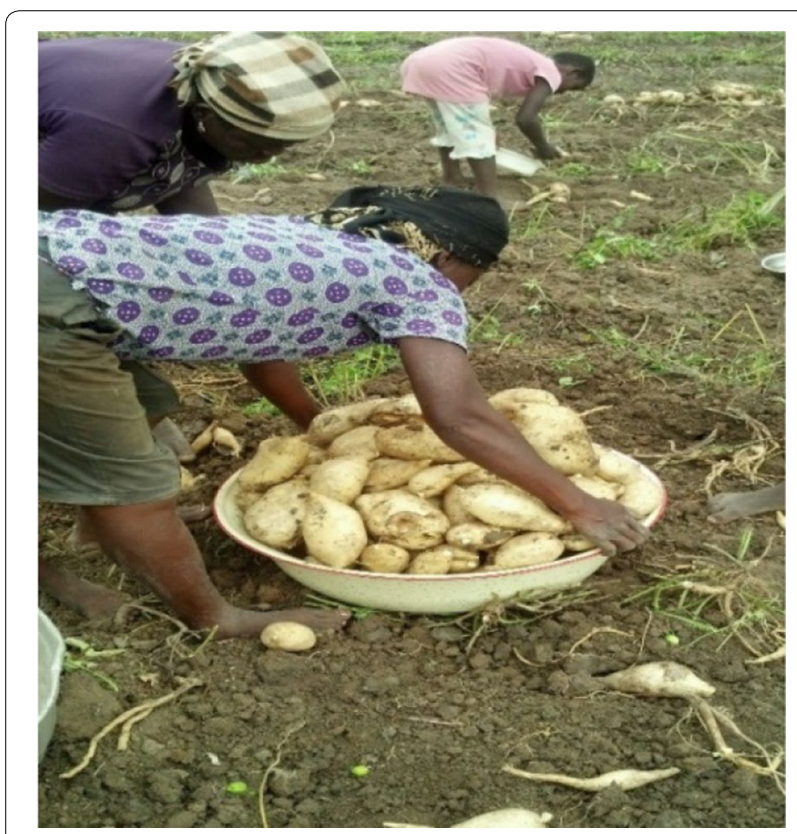

Fig. 9 Basin of sweet potato tubers hectare for better productivity. The average yield of sweet potato ranges from 6.5 tons to 15.125 tons/ha. The high yields were obtained with adequate control measures and were of 275 basins or 15.125 tons per ha which was above the average yield in other African countries such as Kenya and Ethiopia. [15] in their review on sweet potato production constraints reported that the average yield of sweet potato in Ethiopia was 8 tons/ha but below 18 tons/ ha in the Asian countries. This indicates that the production constraints need to be properly addressed in order to improve the productivity of sweet potato in Benin so as to better the yields obtained by Asia countries.

Furthermore, the cultivation of sweet potato crop is facing with other difficulties such as weeding. This is a serious problem due to the nature of the soil (clay) and the lack of manpower in the areas of study. The results of our surveys showed that some producers, considering the high cost of labor, reduced the number of weeding during the sweet potato development cycle. The decline in yield observed in some respondents' fields was due to the lack of weeding. Our results are consistent with those of [16] who reported yield losses of $22 \%$ in India and 57\% in Africa from non-weeded farms of sweet potato. Another constraint is related to the attack of pathogens and insect pests such as black rot, Alternaria blight, cylas spp. (weevils) and caterpillars which cause enormous damage and reduced the market value of the produce. This could be due to the single-crop farming adopted year after year in the areas. Tefera et al. [17] have also reported sweet potato virus disease as a major constraint of sweet potato production in Ethiopia and they also, reported that Alternaria blight was a constraint even though not serious. As a control measures, [18] in Nigeria reported that a mixture of $50 \mathrm{~mL}$ of neem seed oil extract and $30 \mathrm{~mL}$ of diazinon in either 2 or $10 \mathrm{~L}$ of water and cuttings dipped for $30 \mathrm{~min}$ (unconventional 


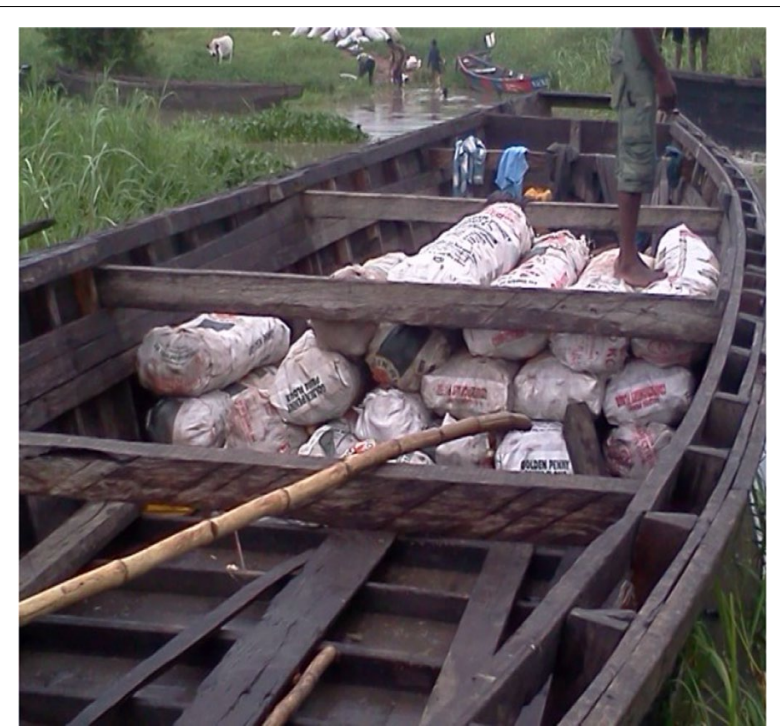

Fig. 10 Transport of sweet potatoes

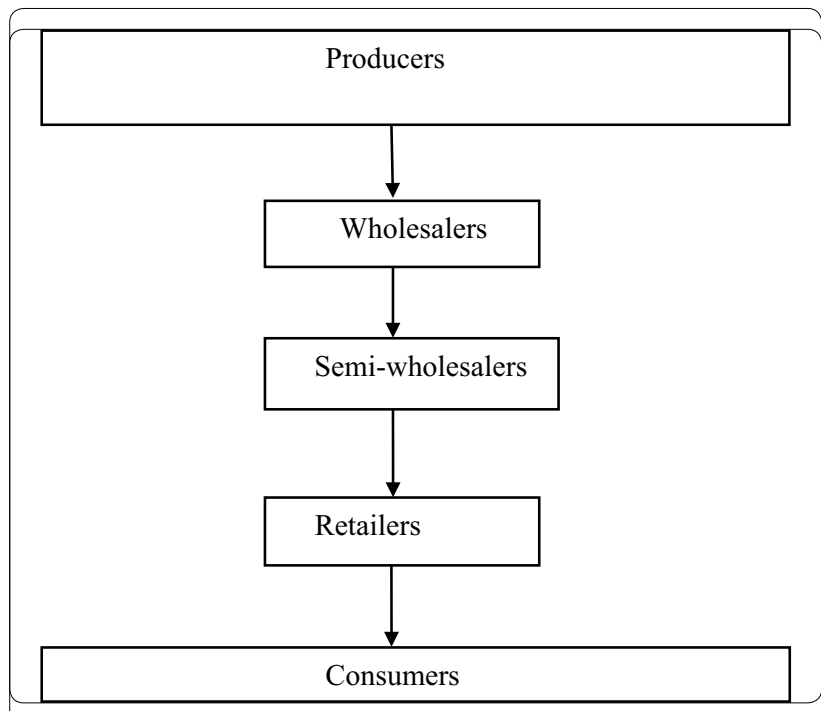

Fig. 11 Sweet potato value chain

weevil control method) controlled Cylas puncticollis by $35.5 \%$. Producers used the sweet potato planting materials from the previous crop because of the non-availability of certified planting materials of sweet potato tolerant to pathogens and pests in the country. This indicates the reason why there are disease and pest infestations in the field and low yields. Fuglie [19] carried out a survey work on constraints across many countries and similarly found that lack of clean and enough planting material was a major constraint in most of African countries. The respondents' training could help limit the number of successive crops on the same plot and adopt crop rotation or crop associations to avoid the buildup of diseases and insects of sweet potato in the farms. According to [13], these practices have many advantages in optimizing production and maintaining soil fertility. In the same vain, [20] also reported the need to improve and build the capacity of farmers. They further stated that the lack of resistant varieties as well as disease- and pest-free sweet potato planting materials were the major hindrance to pest and disease control. Henceforth, breeders need to identify resistant varieties as well as promote production of clean seed to improve sweet potato production. This is consistent with the study of [21] on resistance gene expression on sweet potato virus resistance. The farmers did not apply mineral fertilizers to sweet potato plants due to the fact that they considered their fields fertile. They stated that there is frequent inundation in every rainy season due to the overflow of the rivers and drought in dry season which help in maintaining the fertility of their soils. Producers are also confronted with water problems because of the poor distribution of rainfall in recent years due to climate change, which hampers the development of seedlings and do affect negatively the productivity. After the harvest, producers were compelled to sell their produces at low price because of the storage problem, i.e., the difficulties of conservation due to lack of adequate facilities and the recalcitrant nature of sweet potato tubers. The different methods of short storage observed by respondents are the collection of tubers by women during harvest and put them together in heaps and covered them with plant debris as showed in Fig. 5. The storage period varies between 1 and 2 months if the ridges are not flooded before harvest. A second method consists in conditioning the sweet potatoes in the bags and protecting them with vegetable debris (Fig. 6). The storage period using this second method is just 7 days for the sweet potatoes to be sold to avoid rotting. Sweet potato producers really need better strategies that will allow them to better conserve their crops and sell highquality sweet potatoes under the best storage practices, especially when demand is high in the market and for high income. For sustainable field preservation in order to avoid insect attack, [8] suggested the cutting of all the potato biomass at the end of the rainy season, the remaking of the ridges so as to damage the eggs of the weevils and covering the exposed tubers and the regrowth should be regularly cut. The tubers are thus kept in the field until the beginning of the rains. This practice also makes it possible to better conserve the tubers and to sell them during periods of high demand [8]. Hue and Low [22] also reported that many works have testified about the significant effectiveness of Bacillus thuringiensis in controlling diverse pests of sweet potato including cylas spp. 


\section{Conclusion}

Sweet potato is a crop with high nutritional value and is classified as the most energy-rich tuber. The findings of this work reveal that the lands are fertile to grow sweet potato in the area but it is yet to be grown in a large scale as the farm size varies from $<1$ to $>3$ ha. The main constraints are flooding, diseases and insect infestations which reduce the productivity of sweet potato in the area of study. Farmers don't have access to certified planting materials resistant to pathogens and insect pests. Therefore, appropriate measures need to be taken for their proper control in order to increase the return of farmers. This is followed by poor tubers due diseases and insects, low market price, scarcity and high cost of labor, and the lack of better conservation methods for a long time, low yield. Additionally, farmers don't benefit from their labor when considered the profit made by other actors along the value chain and this need to be tackled by policy makers so as lessen the suffering of the producers. The policy makers must also invest in inputs which they could subsidy for the benefit of farmer, and also invest in modern tools for long-term storage and in research at national level for the researchers to develop certified and resistant sweet cultivars to pathogens and insect pests which could be available to farmers year round. This will definitely lead to sweet potato tubers free of diseases and pest infestation (high marketable sweet potato) which will also result in improving the high market value of sweet potato along the value chain.

\footnotetext{
Authors' contributions

VE designed the study, RHB and CMIK collected and analyzed data and drafted the manuscript. VE, QF, BFC, EMGK and AA supervised data analysis and revised the manuscript. All authors read and approved the final manuscript.
}

\section{Authors' information}

RHB and CMIK are Research Assistants at University of Abomey-Calavi. VE and $\mathrm{QF}(\mathrm{PhD})$ are lecturers in Plant breeding and genetics at University of AbomeyCalavi, Department of Crop Science. BFC is a lecturer in food science at University of Abomey-Calavi. AA is a Professor at Department of Crop Science, University of Abomey-Calavi. EMGK is a PhD candidate at Institut National de la Recherche Scientifique - Eau Terre Enironnement (INRS-ETE), Canada.

\section{Author details}

${ }^{1}$ Department of Crop Production, Faculty of Agricultural Science, University of Abomey-Calavi, Abomey-Calavi, Benin. ${ }^{2}$ Institut National de la Recherche Scientifique - Eau Terre Enironnement (INRS-ETE), Quebec, Canada. ${ }^{3}$ Department of Food Science, Faculty of Agricultural Science, University of AbomeyCalavi, Abomey-Calavi, Benin

\section{Acknowledgements}

We really thank sweet potato producers for their time spent giving us information related to production and marketing of sweet potato.

\section{Competing interests}

The authors declare that they have no competing interests.

\section{Availability of data and materials}

The datasets supporting the conclusions of this article are included within the article.

\section{Consent for publication}

The respondents were informed that their opinions were to be published in a scientific paper and gave their approval.

\section{Ethics approval and consent to participate}

No ethical approval was needed for this study. Prior to data collection, participants gave oral consent to participate in the study.

\section{Funding}

Not applicable.

\section{Publisher's Note}

Springer Nature remains neutral with regard to jurisdictional claims in published maps and institutional affiliations.

Received: 29 June 2017 Accepted: 24 January 2018

Published online: 01 June 2018

\section{References}

1. Adégbola P. Analyse de la filière patate douce au Bénin, PDRT/MAEP. Rapport final 2003; 162p.

2. Egbe OM, Afuape SO, Idoko JA. Performance of improved sweet potato (Ipomea batatas L.) varieties in Makurdi, Southern Guinea Savanna of Nigeria. Am J Exp Agric. 2012;2(4):573-86.

3. Tottappily G, Loebenstein G. The sweet potato. New York: Springer; 2009.

4. Ishida H, Suzuno H, Sugiyama N, Innami S, Tadokoro T, Maekawa A. Nutritive evaluation on chemical components of leaves, stalks and stems of sweet potatoes (Ipomoea batatas poir). Food Chem. 2000;68(3):359-67.

5. Laurie SM, van Jaarsveld PJ, Faber M, Philpott MF, Labuschagne MT. Trans$\mathrm{b}$-carotene, selected mineral content and potential nutritional contribution of 12 sweet potato varieties. J Food Compos Anal. 2012;27:151-9.

6. Oloo BO, Shitandi A, Mahungu S, Malinga JB, Ogata BR. Effects of lactic acid fermentation on the retention of beta carotene content in orange fleshed sweet potatoes. Int J Food Stud. 2014;3:13-33.

7. Sanoussi AF, Dansi A, Ahissou H, Adebowale A, Sanni LO, Orobiyi A, Dansi M, Azokpota P, Sanni A. Possibilities of sweet potato [lpomoea batatas (L.) Lam] value chain upgrading as revealed by physico-chemical composition of ten elites landraces of Benin. Afr J Biotechnol. 2016;15(13):481-9.

8. Countrystat Benin. Food and agriculture data network 2017.

9. Jackai LE, Sosinski B., Jackson DM et al. Occurrence and intra-specific variation of sweetpotato weevil (Brentidae: Coleoptera) in relation to its potential spread in southern United States of America and the Caribbean. In: ISHS acta horticulture 703: II international symposium on sweetpotato and cassava: innovative technologies for commercialization, p. 197-204, International Society for Horticultural Science, Leuven, Belgium; 2006.

10. Agueguia A, Fontem DA, Mbahe RE, Mboua JC, Mouen M, Ngo Som J, Poné Kamdem D, Tchuanyo M, Zok S. La patate douce: un potentiel trop peu connu; 2000. http://www.fao.org/wairdocs/×5695f/x5695f05.htm. Accessed 12 Feb 2017.

11. Muthoni JJ, Shimelis H, Melis R. Potato production in kenya: farming systems and production constraints. J Agric Sci. 2013;5(5):182-97.

12. Gebru H, Mohammed A, Dechassa N, Belew D. Assessment of production practices of smallholder potato (Solanum tuberosum L.) farmers in Wolaita zone, southern Ethiopia. Agric Food Secur. 2017;6:31. https://doi. org/10.1186/s40066-017-0106-8.

13. Doss CR. Understanding farm level technology adoption: lessons learned from CIMMYT's micro surveys in Eastern Africa. CIMMYT Economics Working Paper. Mexico, DF: CIMMYT. 2003; p. iv, 20.

14. Aho N, Kossou DK. Précis d'agriculture tropicale. Bases et Eléments d'applications, les éditions du Flamboyant 1997, Cotonou, p. 464.

15. Shonga E, Gemu M, Tadesse T, Urage E. Review of entomological research on sweet potato in Ethiopia. Discourse J Agric Food Sci. 2013;1:83-92.

16. Degras L. Le Technicien d'Agriculture Tropicale, La Patate Douce. Paris: Editions Maisonneuve et Larose; 1998.

17. Tefera TT, Handoro F, Gemu M. Prevalence, incidence and distribution of Sweet potato virus: it's effect on the yield of sweet potato in Southern region of Ethiopia. Int J Sci Res. 2013;2:591-5. 
18. Ehisianya CN, Ukeh DA, Isah MD, Lale NES, Umeozor OC. Field efficacy of Neem seed oil and diazinon in the management of sweetpotato weevil, Cylas puncticollis (Boh.) in south eastern Nigeria. J Plant Stud. 2013;2:135-44.

19. Fuglie KO. Priorities for sweet potato research in developing countries: results of a survey. HortScience. 2007:42:1200-6.

20. Degu G, Markos D, Bekele A, Kassie M. Community survey and on-farm trials for conservation agriculture to enhance adoption and its impact. Int J Sci Eng Res. 2013;4:1225-35.
21. McGregor CE, Miano DW, LaBonte DR, Hoy M, Clark CA, Rosa GJM. Differential gene expression of resistant and susceptible sweet potato plants after infection with the causal agents of Sweet potato virus disease. J Am Soc Hortic Sci. 2009;134:658-66.

22. Hue S-M, Low M-Y. An insight into sweet potato weevils management: a review. Psyche. 2015, Article ID 849560. http://dx.doi. org/10.1155/2015/849560.

\section{Submit your next manuscript to BioMed Central and we will help you at every step:}

- We accept pre-submission inquiries

- Our selector tool helps you to find the most relevant journal

- We provide round the clock customer support

- Convenient online submission

- Thorough peer review

- Inclusion in PubMed and all major indexing services

- Maximum visibility for your research

Submit your manuscript at

www.biomedcentral.com/submit 